\title{
Uranium-rich monazite-(Ce) from the Krivá type granitic cobbles in conglomerates of the Pieniny Klippen Belt, Western Carpathians, Slovakia: composition, age determination and possible source areas
}

\author{
Pavel UHER ${ }^{1, *}$, Dušan PLAŠIENKA ${ }^{2}$, Martin ONDREJKA ${ }^{1}$, \\ L'ubomír HRAŠKO ${ }^{3}$ and Patrik KONEČNY' ${ }^{3}$
}

1 Department of Mineralogy and Petrology, Faculty of Natural Sciences, Comenius University, Mlynská dolina G, 84215 Bratislava, Slovakia

2 Department of Geology and Paleontology, Faculty of Natural Sciences, Comenius University, Mlynská dolina G, 84215 Bratislava, Slovakia

3 State Geological Institute of Dionýz Štúr, Mlynská dolina 1, 81704 Bratislava, Slovakia

Uher P., Plašienka D., Ondrejka M., Hraško L. and Konečný P. (2013) Uranium-rich monazite-(Ce) from the Krivá type granitic boulders in conglomerates of the Pieniny Klippen Belt, Western Carpathians, Slovakia: composition, age determination and possible source areas. Geological Quarterly, 57 (2): 343-352, doi: 10.7306/gq.1089

Monazite-(Ce) is a widespread accessory mineral in granitic cobbles of the Krivá type (Zástranie and Krivá localities) in polymict conglomerates of Cretaceous flysch sequences, the Pieniny Klippen Belt, Western Carpathians, NW Slovakia. The granites show leucocratic muscovite-biotite granodiorite composition and peraluminous calc-alkaline, S-type character. The monazite contains unusually high $\mathrm{U}$, commonly 1 to 3 , and in some places up to $6.6 \mathrm{wt} \% \mathrm{UO}_{2}$, together with 5 to 7.7 wt. $\%$ $\mathrm{ThO}_{2}$. A cheralite-type substitution $[\mathrm{Ca}(\mathrm{U}, \mathrm{Th}) \mathrm{REE}-2]$ is the dominant mechanism of $\mathrm{U}^{4+}+\mathrm{Th}^{4+}$ incorporation into the monazite structure in the Zástranie sample, whereas both cheralite- and huttonite-type substitution $\left[\left(T_{h}, U\right) S_{i R E} E_{-1} P_{-1}\right]$ are evident in the Krivá granitic cobble. Uranium alone prefers the $\mathrm{CaU}^{4+}(\mathrm{REE})_{-2}$ mechanism, whereas Th favours the huttonite substitution. The chemical U-Th-Pb dating of monazite from both granitic cobbles show an Early Carboniferous age (346 \pm $2 \mathrm{Ma}$ ), which is consistent with the main meso-Variscan, orogen-related plutonic activity in the Central Carpathian area (Tatric and Veporic superunits). Analogous U-rich monazites were detected in some Variscan S-type leucogranites of the Rimavica massif (South Veporic Unit) and the Bojná and Bratislava massifs (northern part of the Tatric Unit). On the basis of structural and palaeogeographic data, the North Tatric Zone is the most plausible source of the monazite-bearing granitic boulders in the Pieniny Klippen Belt. However, the source granitic body was most likely hidden by ensuing tectonic shortening along the northern Tatric edge after deposition of the Coniacian-Santonian Upohlav type conglomerates.

Key words: uranium-rich monazite, granite, conglomerate, monazite dating, Pieniny Klippen Belt, Western Carpathians.

\section{INTRODUCTION}

Granitic clasts are characteristic rocks in polymict conglomerate beds in Cretaceous flysch sequences of the Kysuce, Klape and Manín units in the Western Carpathian Pieniny Klippen Belt (PKB). In addition to dominant carbonates and acid to basic volcanic rocks, intrusive rocks (mainly granites) compose 0.4 to 13 vol. \% of the total clasts in PKB conglomerates (Marschalko, 1986). Two basic types of granitic clasts from pebble and cobble to boulder size have been distinguished in the PKB since early studies. These are the "Tatry-like" and "exotic" types (Zoubek, 1931; Andrusov, 1938). The first type

\footnotetext{
* Corresponding author: puher@fns.uniba.sk

Received: January 22, 2013; accepted: March 28, 2013; first published online: April 24, 2013
}

shows petrographic and geochemical similarities to common Variscan (Carboniferous) granitic rocks of the Tatric and Veporic superunits of the Central Western Carpathians, while the second group contains granitic rocks "exotic" for the West Carpathian basement (Wieser, 1958; Krivý, 1969; Kamenický et al., 1974; Šímová, 1985; Birkenmajer and Skupiński, 1989). Detailed mineralogical, geochemical and geo-chronological studies of the "exotic", Upohlav type granitic rocks reveal their post-orogenic, A-type affinity and Permian age, whereas the "Tatry-like" (Krivá and Lubina types) magmatites show calc-alkaline and orogen-related I/S-type trend, comparable with other West Carpathian Variscan (Carboniferous) suites (Uher and Marschalko, 1993; Uher et al., 1994; Uher and Pushkarev, 1994). Trace-element geochemistry, accessory minerals and zircon isotopic $\mathrm{U}-\mathrm{Pb}$ dating indicate the similarities between the "exotic" Upohlav type granitic clasts and especially the Turčok A-type granite in the Gemeric Superunit (Uher and Broska, 1996; Broska and Uher, 2001; Radvanec et al., 2009). 
On the other hand, there is only restricted data concerning the Krivá ("Tatry-like") type granitic boulders of the PKB. Preliminary electron-microprobe $\mathrm{U}-\mathrm{Th}-\mathrm{Pb}$ dating of monazite from one Krivá type granite clast supports their Variscan and Carboniferous age (Finger et al., 2003). Our recent microprobe dating and analyses of monazite in these granites initiated the more detailed research presented in this paper. The aims of our study include (1) more precise age determination of the Krivá type granitic clasts, (2) the characterization and significance of uranium-rich monazite in studied granitic rocks, and (3) discussion of the possible source area of the Krivá type granitic clasts in the PKB Cretaceous flysch, based on older and new results.

\section{REGIONAL GEOLOGY AND LOCATION OF SAMPLES}

The studied granitic boulders were collected from the Upohlav type conglomerate beds of the Coniacian-Santonian Sromowce Formation in the Kysuca-Pieniny and/or Klape Unit of the Pieniny Klippen Belt in northwestern Slovakia. The Upohlav polymict conglomerates occur in several stratigraphic horizons. They form stratiform bodies usually 3 to $20 \mathrm{~m}$ thick, intercalating with polycyclic sandstone and mudstone beds as parts of deep-marine flysch turbidite sequences (e.g., Marschalko, 1986; Starek et al., 2010).

Palaeontological and stratigraphical evidence indicate Cretaceous, Albian to Maastrichtian age of the Upohlav conglomerate beds in the western Slovak segment of the Pieniny Klippen Belt (Marschalko, 1986; Mišík and Marschalko, 1988).

Two typical conglomerate occurrences containing the Krivá type granite clasts (mainly of cobble size) were selected for our research: Zástranie and Krivá (Fig. 1). The Zástranie locality (BP-8 sample) exhibits conglomerate outcrops near Zástranie village, in the vicinity of the town of Žilina, approximately $1500 \mathrm{~m} / 322^{\circ}$ from elevation point Straník (769 m a.s.I.). The Krivá locality (BP-10 sample) is a large conglomerate outcrop in the Orava Valley, between the Krivá and Dlhá nad Oravou settlements, approximately $1000 \mathrm{~m} / 164^{\circ}$ from the elevation point Vysoký grúň (849 m a.s.I.). Detailed investigation indicated Turonian to Coniacian age for the Krivá (Klape Unit) and Coniacian age for the Zástranie (Pieniny Unit) conglomerate beds (Marschalko, 1986).

\section{ANALYTICAL METHODS}

Rock-forming minerals of the granitic cobbles were studied in polished thin sections. Standard modal analysis was counted on the basis of approximately 3,000 points for both samples.

The monazite internal texture, chemical composition and age were investigated by electron microprobe in polished thin sections using a Cameca SX100 electron microprobe at the Dionýz Štúr State Geological Institute, Bratislava. Monazite dating needs specific measuring conditions as required in trace element dating. These include high sample current and a long counting period. The sample current of $180 \mathrm{nA}$ and counting times of $300 \mathrm{~s}$ for $\mathrm{Pb}, 80 \mathrm{~s}$ for $\mathrm{U}$ and $35 \mathrm{~s}$ for Th were used for more accurate measurement. The accelerating voltage of $15 \mathrm{kV}$ was preferred to $20 \mathrm{kV}$, as it provides better spatial resolution, it is less harmful in surface damage and it reduces PAP matrix correction factors. Large crystals (LPET and LLIF) were used, as these are several times more sensitive than conventional ones. Elements were measured as follows: As, Si, Al were measured with TAP: $\mathrm{P}, \mathrm{Pb}$, Th, U, Y, S, Ca, Sr with LPET and REE and $Y$ with LLIF crystal. The following standards and spectral lines were used: barite $(\mathrm{S} K \alpha)$, apatite $(\mathrm{PK} \alpha), \mathrm{GaAs}$ $(\mathrm{As} L \alpha)$, wollastonite $(\mathrm{Si} K \alpha, \mathrm{CaK} \alpha)$, zircon $(\mathrm{Zr} L \alpha), \mathrm{ThO}_{2}$ (ThM $\alpha), \mathrm{UO}_{2}(\mathrm{UM} \beta), \mathrm{Al}_{2} \mathrm{O}_{3}(\mathrm{Al} K \alpha), \mathrm{YPO}_{4}(\mathrm{YL} \alpha), \mathrm{LaPO}_{4}(\mathrm{LaL} \alpha)$, $\mathrm{CePO}_{4}(\mathrm{Ce} L \alpha), \mathrm{PrPO}_{4}(\mathrm{Pr} L \alpha), \mathrm{NdPO}_{4}(\mathrm{Nd} L \beta), \mathrm{SmPO}_{4}(\mathrm{Sm} L \beta)$, $\mathrm{EuPO}_{4}(\mathrm{Eu} L \beta), \mathrm{GdPO}_{4}(\mathrm{Gd} L \alpha), \mathrm{TbPO}_{4}(\mathrm{~Tb} L \alpha), \mathrm{DyPO}_{4}(\mathrm{Dy} L \alpha)$, $\mathrm{HoPO}_{4}(\mathrm{HoL} \beta), \mathrm{ErPO}_{4}(\mathrm{ErL} \beta), \mathrm{TmPO}_{4}(\mathrm{Tm} L \alpha), \mathrm{YbPO}_{4}(\mathrm{Yb} L \alpha)$, $\mathrm{LuPO}_{4}(\mathrm{Lu} L \beta)$, fayalite $(\mathrm{FeK} \alpha), \mathrm{SrTiO}_{3}(\mathrm{SrL} \alpha)$, barite $(\mathrm{Ba} L \alpha)$, and $\mathrm{PbCO}_{3}(\mathrm{PbM} \alpha)$. Special care was taken to ensure that line overlaps were properly corrected and that background positions were clear of interfering lines among the REE. We used empirically determined correction factors applied to the following line overlaps: $\mathrm{Th} \rightarrow \mathrm{U}$, Dy $\rightarrow \mathrm{Eu}, \mathrm{Gd} \rightarrow \mathrm{Ho}, \mathrm{La} \rightarrow \mathrm{Gd}, \mathrm{Ce} \rightarrow$ $\mathrm{Gd}, \mathrm{Eu} \rightarrow \mathrm{Er}, \mathrm{Gd} \rightarrow \mathrm{Er}, \mathrm{Sm} \rightarrow \mathrm{Tm}, \mathrm{Dy} \rightarrow \mathrm{Lu}, \mathrm{Ho} \rightarrow \mathrm{Lu}, \mathrm{Yb} \rightarrow \mathrm{Lu}$, and Dy $\rightarrow$ As (Konečný et al., 2004). The matrix effects were corrected by the PAP procedure. The resultant age was calculated using the mathematical model proposed by Montel et al. (1996). The resultant age is the weighted average of a group of apparent ages (from point analysis). Analyses acquired during the monazite dating procedure involve a complete set of elements usable for study of exchange substitution reactions in monazite. Analyses with non-dating procedure were added to expand the dataset. These were analysed under the measurement conditions of $15 \mathrm{kV}, 40 \mathrm{nA}$ and 5-10 $\mu \mathrm{m}$ beam diameter, and the counting time varied from 20 to 120 s depending on the sensitivity of the given analytical line.

The accuracy of HREE (especially $\mathrm{Ho}$ to $\mathrm{Lu}$ ) present in monazite at low concentrations (generally $<0.5$ wt. $\% \mathrm{HREE}_{2} \mathrm{O}_{3}$ ) is lower than desired, and the geological interpretation of such values can be ambiguous. The detection limit for LREE is $0.09-0.12$ wt. \%, HREE (Dy to Lu) $0.15-0.19$ wt. \%, and for other elements it is less than 0.09 wt.\%.

\section{RESULTS}

\section{CHARACTERIZATION OF GRANITIC CLASTS}

Both studied cobbles (approximately $10 \mathrm{~cm}$ in size) represent equigranular to slightly porphyric, medium-grained granitic rocks without preferential mineral orientation or schistose structure. Anhedral quartz shows distinct undulatory extinction. Subhedral to euhedral plagioclase commonly occurs in the central parts of larger interstitial perthitic K-feldspar. Plagioclase is slightly altered by fine-crystalline white mica aggregates (sericitization). Subhedral to anhedral biotite is commonly altered to chlorite. In some places, muscovite replaced biotite or plagioclase, while thin veinlets $(<0.1 \mathrm{~mm})$ of secondary calcite cut the rock-forming minerals in others. Apatite, rutile, zircon and garnet were identified as accessory minerals.

1. The Zástranie sample (BP-8) is classified as biotite leucogranodiorite. In vol.\% it contains: 37.1 - quartz, 43.9 - plagioclase, 14.9 - K-feldspar, 3.5 - biotite $( \pm$ chlorite), 0.5 - muscovite and 0.1 - accessory minerals. 2. The Krivá sample (BP-10) is two-mica granodiorite. In vol. \% it contains: 33.5 - quartz, 48.0 - plagioclase, 9.5 K-feldspar, 7.6 - biotite ( \pm chlorite), 1.3 - muscovite and 0.1 - accessory minerals.

The chemical composition of both granitic rocks (BP-8 and BP-10.1; Uher et al., 1994) and also the zircon typological and compositional study (Uher and Marschalko, 1993) indicate their peraluminous, calc-alkaline and orogen-related character with S-type tendency. 


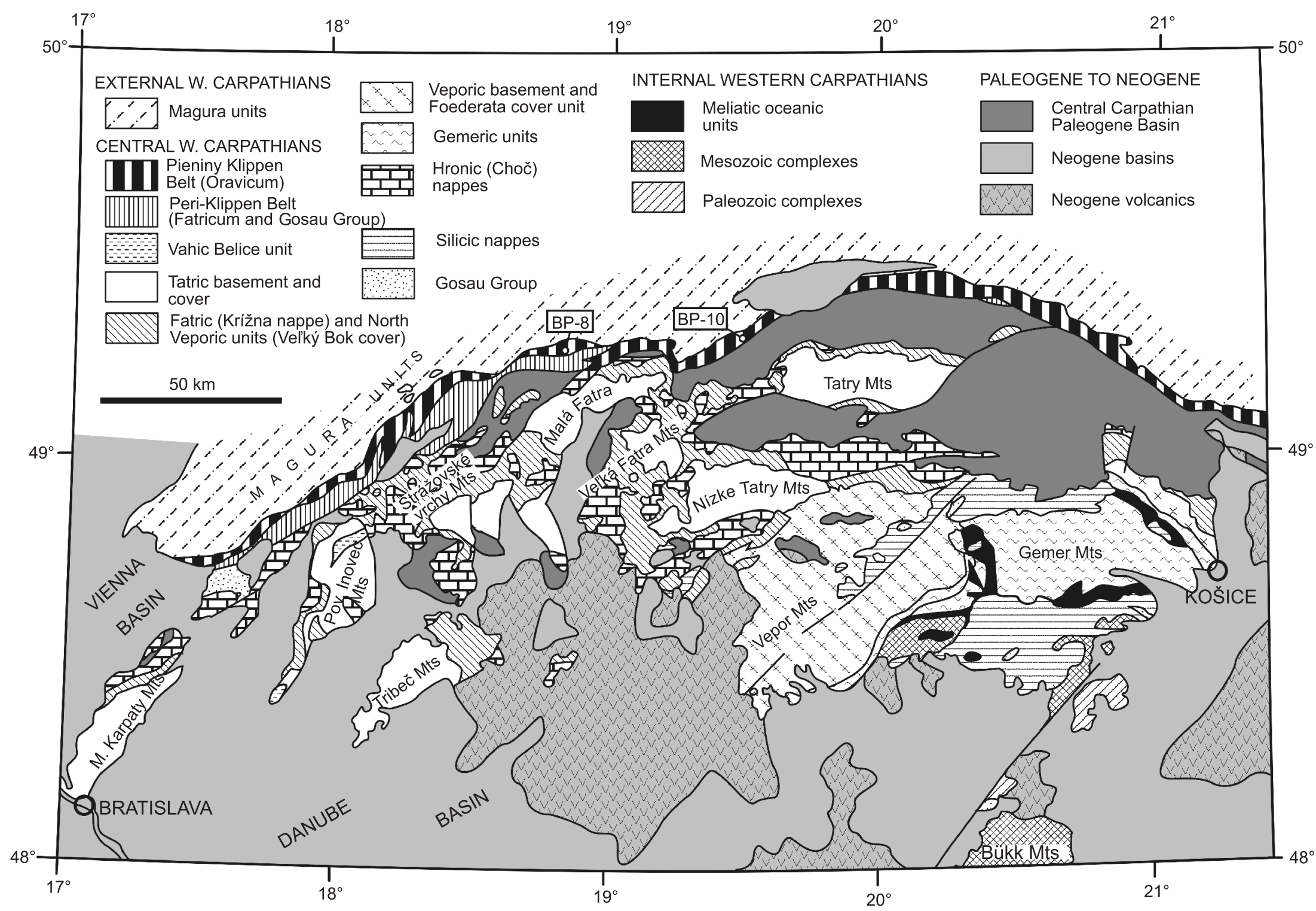

Fig. 1. Geological map of the Western Carpathians with positions of the analysed samples 
MONAZITE PROPERTIES AND ASSOCIATED MINERALS

Monazite-(Ce) is a characteristic accessory mineral in both investigated granite samples. It usually forms euhedral to subhedral crystals (approximately 15 to $200 \mu \mathrm{m}$ across), in association with plagioclase, quartz, biotite, muscovite, apatite, zircon, xenotime-(Y), $\mathrm{ThSiO}_{4}$-phase and pyrite (Fig. 2). Under back-scattered electron mode (BSE), monazite crystals reveal relatively homogeneous internal texture and occasionally they display regular or irregular slightly brighter rim zones. Primary magmatic inclusions of zircon and xenotime-( $\mathrm{Y})$ in monazite(Ce) were detected (Fig. 2B, D). Some monazite crystals show alteration phenomena (Fig. $2 \mathrm{~A}, \mathrm{C}$ ). This is most likely due to their subsolidus partial dissolution and reprecipitation; with perforated internal texture, irregular rims, secondary anhedral inclusions of $\mathrm{ThSiO}_{4}$-phase (thorite or huttonite), uraninite, apatite or pyrite, and in some places there are overgrowths of $\mathrm{TiO}_{2}$-phase (secondary rutile, anatase or brookite?), apatite, chlorite, and muscovite.

\section{MONAZITE COMPOSITION AND DATING}

Electron-microprobe analyses $(n=64)$ show monazite- $(\mathrm{Ce})$ compositions, where $\mathrm{Ce}^{3+}$ is a distinctly dominant REE cation and $\mathrm{Ce}>\mathrm{La}, \mathrm{Nd}>\mathrm{Pr}>\mathrm{Sm}$ distribution of the REE's occurs (Ap- pendix $\left.1^{*}\right)$. The most characteristic feature of the monazite-(Ce) from the both granitic cobbles (especially from Zástranie) is an unusually high uranium content in majority of monazite crystals, commonly 1 to 3 , and in some places up to $6.6 \mathrm{wt} . \% \mathrm{UO}_{2}$ (up to 0.06 apfu $U$ ), together with 5 to $7.7 \mathrm{wt} \% \mathrm{ThO}_{2}$ (up to $0.07 \mathrm{apfu}$ Th). The U-rich monazite crystals are relatively homogeneous, with high $U$ content detected in the entire crystal. In contrast, $\mathrm{U}$-poor monazite crystals ( $\leq 1 \mathrm{wt} . \% \cup_{2}$ ) were also detected in both investigated samples (Appendix 1, analyses A31, A3, and A27). These U-poor monazites commonly show subsolidus alteration and breakdown coronae with secondary apatite and rutile. Compositional variations of the main elements in monazite $(\mathrm{P}, \mathrm{Si}$, Th, $\mathrm{U}, \mathrm{REE}, \mathrm{Ca})$ indicate a cheralite-type, $\mathrm{Ca}+(\mathrm{U}, \mathrm{Th})=2 \mathrm{REE}$ substitution as the dominant incorporation mechanism of $U^{4+}$ into the monazite structure in the Zástranie sample (BP-8), whereas both cheralite and huttonite type substitutions $[(T h, U)+S i=R E E+P]$ are evident in the Krivá (BP-10) granitic clast (Fig. 3A). Moreover, the $U$ and Th concentrations in both samples exhibit no mutual correlation (Fig. 3B), thus indicating their different geochemical behaviour. Uranium evidently prefers couple-substitution with calcium in a $\mathrm{CaU}^{4+}(\mathrm{REE})_{-2}$ mechanism, whereas Th inclines rather towards the $\mathrm{Th}^{4+} \mathrm{Si}(\mathrm{REE})_{-1} \mathrm{P}_{-1}$ trend (Fig. $3 \mathrm{C}-\mathrm{F}$ ). Two parallel Si vs. Th trends indicate two different monazite compositions:

- Si-rich with dominant huttonite;

- Si-poor with mixed cheralite-huttonite substitution, especially in the Krivá sample (Fig. 3F).
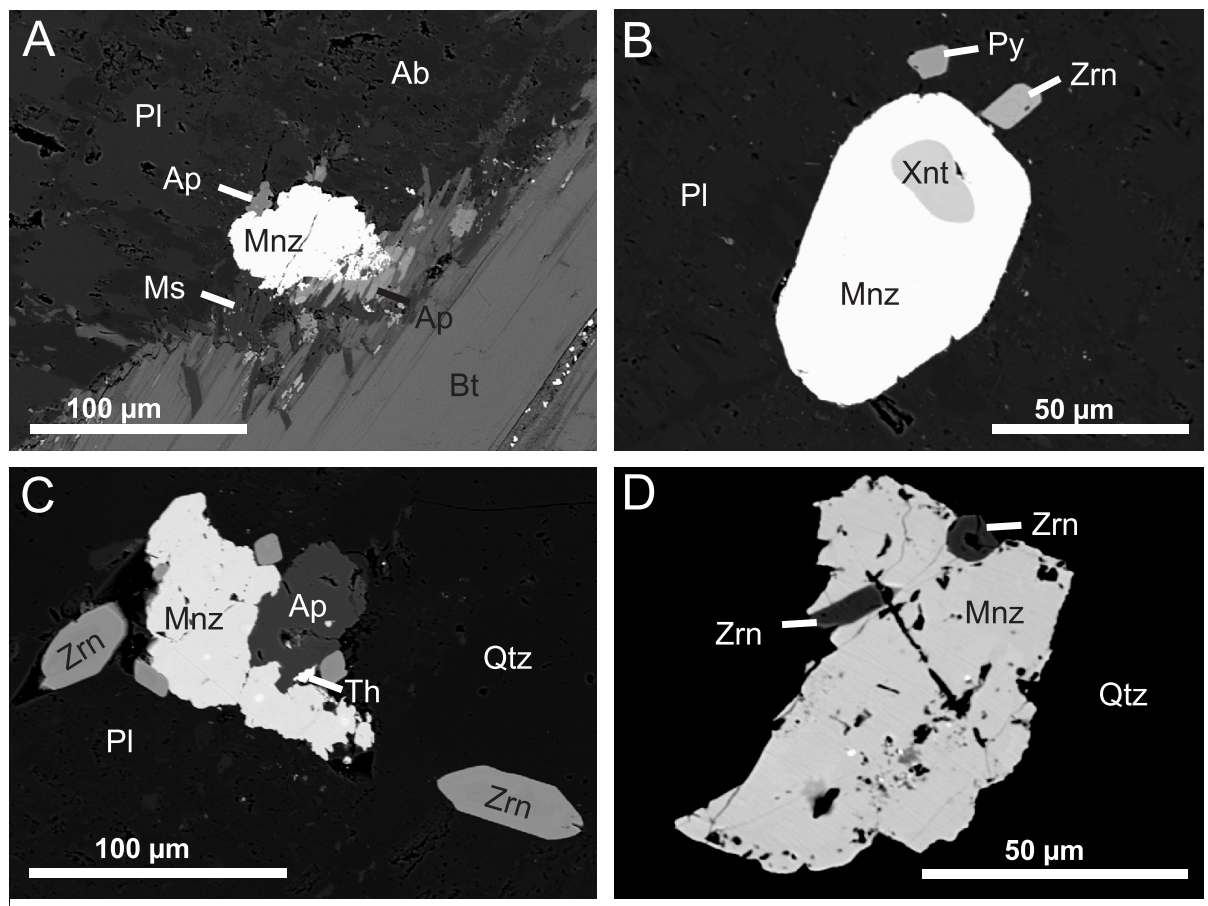

Fig. 2A-D - BSE photomicrographs of monazite-(Ce) and associated rock-forming and accessory minerals in Zástranie (BP-8) and Krivá (BP-10) granitic clasts

$\mathrm{Ab}$ - albite, Ap - apatite, Bt - biotite, Mnz - monazite, Ms - muscovite, Qtz - quartz, $\mathrm{PI}$ - plagioclase, Py - pyrite, $\mathrm{Th}-\mathrm{ThSiO}_{4}$ phase, Xnt - xenotime, Zrn - zircon

\footnotetext{
* Supplementary data associated with this article can be found, in the online version, at doi: $10.7306 / \mathrm{gq} .1089$
} 

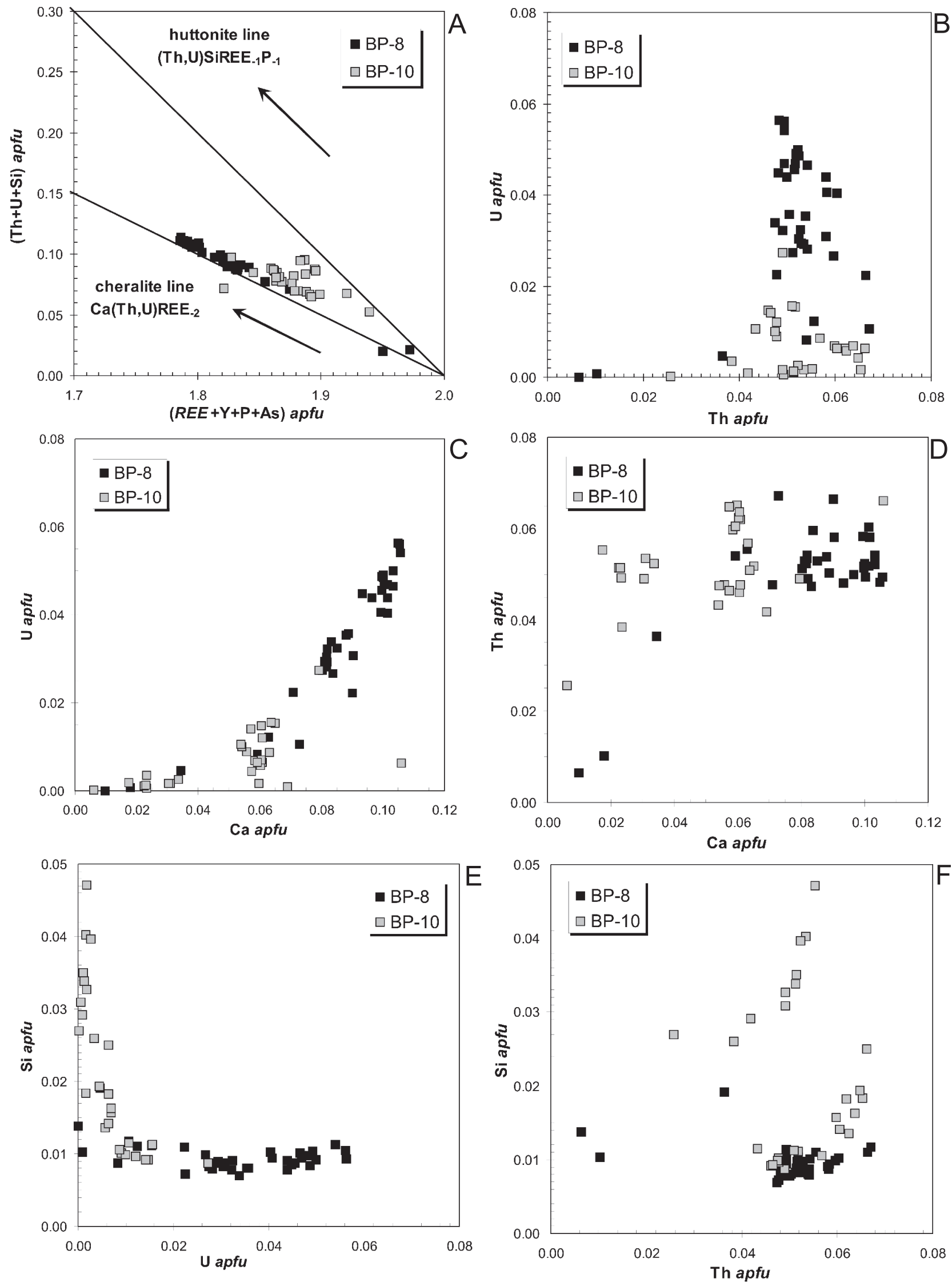

Fig. 3A-F - substitution diagrams of monazite-(Ce) from Zástranie (BP-8) and Krivá (BP-10) granitic clasts (in atoms per formula unit, apfu) 
Concentrations of $\mathrm{Pb}(\sim 0.1$ to 0.4 wt.\% $\mathrm{PbO})$ are proportional to $\mathrm{Th}+\mathrm{U}$, and this indicates the radiogenic origin of lead (Appendix 1). The contents of other measured elements including $\mathrm{S}, \mathrm{As}, \mathrm{Fe}$, heavy REE's, $\mathrm{Sr}$ and $\mathrm{Ba}$ are negligible in both samples.

The calculated electron-microprobe (chemical) U-Th-Pb monazite dating for the studied samples gave very similar Variscan ages: $348 \pm 2 \mathrm{Ma}(n=25)$ for Zástranie, and $338 \pm 4 \mathrm{Ma}(n=22)$ for the Krivá granite boulder. Therefore, we used all analytical data in a unified isochron for both monazite samples with the resultant age of $346 \pm 2 \mathrm{Ma}(\mathrm{n}=47, \mathrm{MSWD}=2.83$; Fig. 4). This relatively high analytical precision of dating is partly due to elevated contents of $U$ in monazite, because the contribution of $U$ to the radiogenic $\mathrm{Pb}$ is a few times higher than that of $\mathrm{Th}$.

\section{DISCUSSION}

\section{URANIUM-RICH MONAZITE}

Natural monazite-(Ce) usually contains $\mathrm{Th}^{4+}$, a cation that partly replaces REE's by two basic heterovalent isomorphic
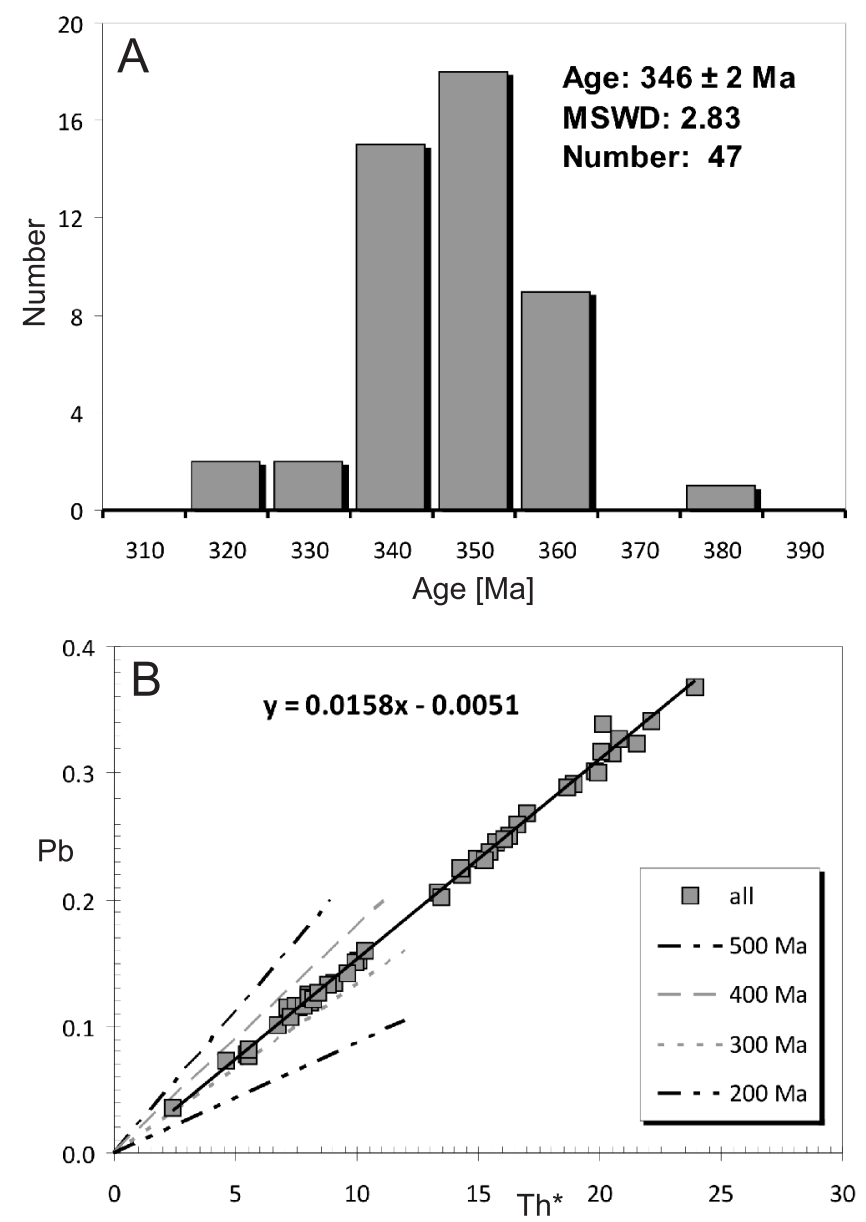

Fig. 4A, B - results of chemical U-Th-Pb dating of monazite-(Ce) from Zástranie (BP-8) and Krivá (BP-10) granitic clasts: monazite age histogram $(\mathrm{A})$ and $\mathrm{Pb}$ vs. Th* (wt.\%) age monazite isochron diagram (B)

$$
T h^{*}=T h+3.15^{*} \mathrm{U}(\text { Nagy et al., 2002) }
$$

mechanisms: (1) ThSiREE ${ }_{-1} \mathrm{P}_{-1}$ (huttonite-type substitution), and (2) CaThREE -2 (cheralite-type substitution). Therefore, the Th content in monazites commonly reaches up to $30 \mathrm{wt} \%$ $\mathrm{ThO}_{2}$, and monazite-huttonite and monazite-cheralite solid solutions have been commonly described in granitic monazites (e.g., Bea, 1996; Förster, 1998, 2006; Williams et al., 2007). Both substitutions are possible due to the similarity of cation radii and other geochemical properties of $\mathrm{Th}^{4+}$ and light $\mathrm{REE}^{3+}$ (mainly $\mathrm{La}^{3+}$ and $\mathrm{Ce}^{3+}$ ). The monoclinic monazite-type structure with dominant large light REE's $\left(\mathrm{La}^{3+}\right.$ to $\left.\mathrm{Sm}^{3+}\right)$ in nine-fold coordination and effective ionic radii of 1.13 to $1.22 \times 10^{-10} \mathrm{~m}$ (Shannon, 1976), prefers larger [9]Th ${ }^{4+}\left(1.09 \times 10^{-10} \mathrm{~m}\right)$, than smaller $[9] \mathrm{U}^{4+}\left(1.05 \times 10^{-10} \mathrm{~m}\right)$. On the other hand, tetragonal xenotime-(Y) and zircon prefer the entry of heavy REE's and $U^{4+}$ with smaller ionic diameters rather than the larger $\mathrm{Th}^{4+}$ cation. Consequently, U-rich monazite $\left(\mathrm{UO}_{2}>1 \mathrm{wt} . \%\right)$ is relatively rare in natural occurrences. The highest $U$ contents in monazite have been described from granitic pegmatites of the Italian Alps, where $\mathrm{UO}_{2}$ occasionally reached 12 to $16 \mathrm{wt} . \%$ (Gramaccioli and Segalstad, 1978; Mannucci et al., 1986), and also from some granitic rocks (3 to $14 \mathrm{wt} \% \mathrm{UO}_{2}$; Gulson and Krogh, 1973; Bea, 1996; Förster, 1998; Appel et al., 2011). The entry of $\mathrm{U}^{4+}$ into the monazite structure is compensated mainly by $\mathrm{Ca}^{2+}$ via CaUREE -2 substitution; and the ThSiREE ${ }_{-1} \mathrm{P}_{-1}$ mechanism is negligible (Gramaccioli and Segalstad, 1978; Manucci et al., 1986; Bea, 1996; Förster, 1998; Appel et al., 2011). The presence of $\mathrm{Ca}_{0.5} \mathrm{U}_{0.5} \mathrm{PO}_{4}$ compound in natural monazites is supported by experimental synthesis of their monoclinic, monazite-structure end-member analogue (Dusasoy et al., 1996; Bregiroux et al., 2007). However, the origin of such a high content of uranium in natural monazite is still unclear. Here, specific enrichment by uranium or increased U/Th ratio in parental magma can possibly be assumed.

\section{POSSIBLE SOURCES OF U-RICH MONAZITES FROM THE PIENINY KLIPPEN BELT GRANITIC CLASTS}

In addition to the granites, various other clasts of problematic provenance have been recognized in the Upohlav type conglomerates. These include the Triassic pelagic limestones, Upper Jurassic platform limestones, Urgonian limestones with serpentinite fragments and $\mathrm{Cr}$-rich spinel and glaucophane grains, Upper Jurassic blueschists and large amounts of basic, intermediate and acid volcanic rocks (for comprehensive reviews of the clasts composition see Mišík and Marschalko, 1988; Birkenmajer, 1988; Marschalko and Rakús, 1997; Mišík and Reháková, 2004). There have been several attempts to identify the source areas of this variable conglomerate material. At the beginning of a systematic study of the PKB structure in western Slovakia, Andrusov $(1931,1938)$ considered the conglomerates to be transgressive and the rock clasts to be derived from the original substratum of the PKB "Pienidic" units. Later on, when the intra-formational character of the conglomerates and their close relationship to synorogenic flysch deposits became clear, the concept of an "exotic cordillera" (Ultrapienidic or Andrusov Ridge) was formulated, and this was maintained for the entire second half of the last century (e.g., Andrusov, 1968, 1974; Mišík and Sýkora, 1981; Birkenmajer, 1986, 1988; Mišík et al., 1991). There have been several concepts of the nature of this ridge: as an elevated imbricated zone in front of the Central Carpathian nappes (Andrusov, 1974), an accretionary complex bearing obducted ophiolites (Mišík, 1978; Mišík and Marschalko, 1988), tectonic slivers within a large-scale transform zone (Marschalko, 1986; Rakús and Marschalko, 1997), a 
Lower Cretaceous magmatic arc in an active margin setting (Marschalko, 1986; Birkenmajer, 1988), and Meliata-related suture complexes in the Inner Carpathian zones (Plašienka, 1995a, 2012; Kissová et al., 2005).

Similar to the situation in other exotic clasts, a direct source of the majority of granitic material in the Upohlav conglomerates is unknown or questionable; at least at the present erosional surface. In general, granitic material occurs in several stratigraphic levels of exotic conglomerates; namely in mid-Cretaceous (Albian-Cenomanian), Upper Cretaceous (Coniacian-Santonian), and in Maastrichtian-Eocene flysch sequences. Concerning the true "exotic" material, encompassing Permian A-type granites (Uher and Marschalko, 1993; Uher and Pushkarev, 1994; Uher et al., 1994), these are present in all three stratigraphic levels. Based on zircon fission-track dating, Kissová et al. (2005) proposed their derivation from a contemporaneous, actively deforming and exhuming mountainous region in the southern Central Carpathian zones in mid-Cretaceous times, while the younger occurrences represent clasts recycled from the original Albian-Cenomanian conglomerates. However, the Krivá type granitic rocks of presumably Tatric or Veporic provenance are only known from the second, Coniacian to Santonian conglomerates. Therefore, their derivation from sources distinct to those of the Permian A-type granites must be considered.

Possible Central Carpathian provenance of the "non-exotic" Krivá type granitic clasts is tested by the following comparison. A systematic compositional study of monazites from the West Carpathian Variscan granitic and pegmatitic rocks (unpublished material of the authors) reveals their generally low concentrations of $U$ (usually 0.1 to 0.3 wt. $\% \cup_{2}$ ). However, monazite from leucogranites and aplites of the Rimavica Massif (southern part of the Veporic Superunit), especially from the Sinec body, contained 3 to $8 \mathrm{wt} \% \mathrm{UO}_{2}$ in some places. Moreover, 1 to $3.7 \mathrm{wt} . \% \mathrm{UO}_{2}$ was rarely detected in monazite from granites of the Bojná Massif (Považský Inovec Mts.) and the Bratislava Massif (Malé Karpaty Mts.), both in the North Tatric Zone. All known occurrences of U-rich monazite in the West Carpathian granitic rocks (Rimavica, Bojná and Bratislava massifs) show similar geochemical features to the Krivá granitic clasts, espe- cially S-type affinity and analogous $\sim 350$ Ma age (e.g., Broska and Uher, 2001; Finger et al., 2003; Kohút et al., 2009).

Two possible sources of the examined Krivá type granitic cobbles are now discussed. The first possibility is the South Veporic Rimavica Massif. The Cretaceous tectonic evolution of the Veporic Superunit was recently reconstructed by Janák et al. (2001) and Jerrábek et al. (2012). Accordingly, the Southern Veporic zones experienced uplift and exhumation in the latest Cretaceous times, i.e. the Rimavica Massif might have been already exhumed and was theoretically able to provide clasts for the Coniacian to Santonian deposits, notwithstanding that published cooling ages (e.g., Putiš et al., 2009 and references therein) do not support this possibility. On the other hand, there are several objections that cast doubt on this supposition. First of all, the Southern Veporic domain is composed of a great variety of rocks in addition to the granitic rocks. These include basement amphibolites, gneisses and micaschists and also various metamorphosed sedimentary cover rocks (Permian and Triassic sandstones and carbonates). However, there is no clast of this provenance recognized in the Upohlav conglomerates. Moreover, there are no clasts of Veporic origin in the Senonian conglomerates of the Gosau Group which were deposited just nearby the exhuming Veporic dome (e.g., Hovorka et al., 1990). Another problem concerns the distance between the possible sources and the actual position of the conglomerates. This is approximately $100 \mathrm{~km}$, and no traces of transport possibilities are recognizable at the present erosional surface (cf. Fig. 5).

The second option is the Bojná and/or Bratislava Massif or similar source located at the outer Tatric margin, and therefore in the proximity of the PKB. This possibility seems more viable for palaeotectonic reasons. The northern Tatric margin experienced shortening and imbrication during the Late Cretaceous (Plašienka, 1995b; Putiš et al., 2009). Coniacian-Santonian conglomerates of the Belice Unit of presumed South PenninicVahic affiliation contain, in addition to various Mesozoic carbonates, also pebbles of aplitic granites and especially micaschists derived from the overriding Tatric Inovec Nappe (Plašienka et al., 1994). It may be inferred that a similar tectonic situation occurred in those parts of the Coniacian-Santonian Upohlav conglomerates which were located nearby sources of the Krivá

NW

(present)

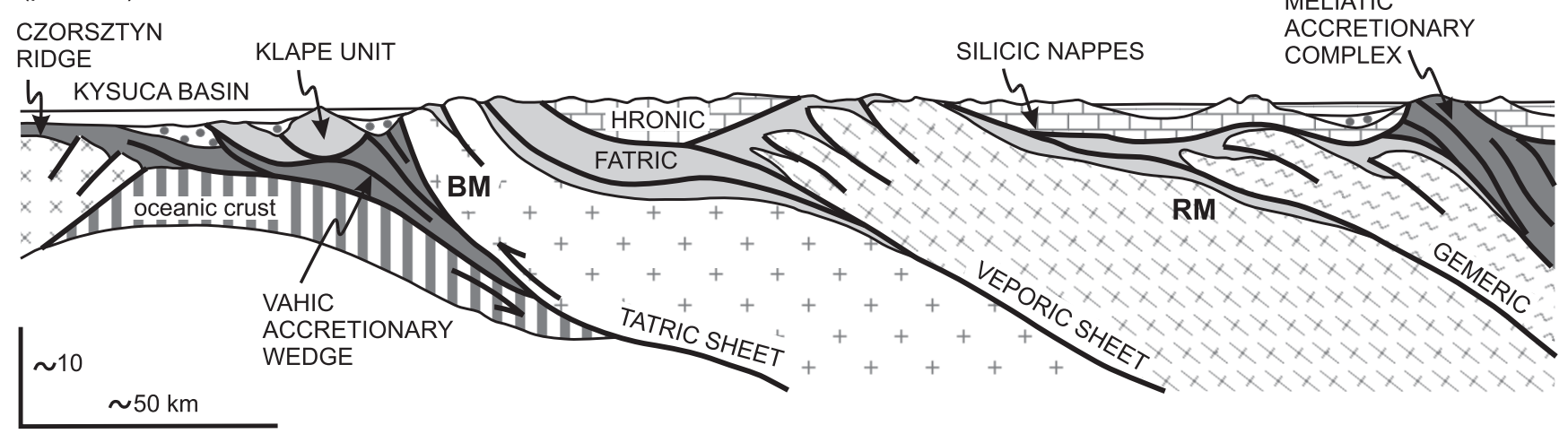

Fig. 5. Conceptual palaeotectonic cross-section through the Western Carpathians at approximately the Coniacian/Santonian boundary (ca. $85 \mathrm{Ma}$ )

The section shows active basins of this age (dotted areas) in front of the Tatric sheet, filled with conglomerates containing granitic clasts analysed in this work. Note that coeval conglomerates deposited in Gosau-type basins adjacent to the Meliatic suture in the southern Carpathian zones do not contain any material derived from possible Veporic sources, but are dominated by Meliatic ophiolitic detritus. Estimated position of the possible sources discussed in the text is indicated by BM (Bojná and Bratislava massifs) and RM (Rimavica Massif) 
type granitic rocks in the Tatric basement (Fig. 5). During subsequent shortening, these sources could have been hidden by overthrusting of the higher Tatric nappes, including the Bojná and Bratislava basement units.

\section{CONCLUSIONS}

Study of accessory monazite-(Ce) in granitic cobbles from the Krivá type (Zástranie and Krivá localities) polymict conglomerates of Cretaceous flysch sequences in the Pieniny Klippen Belt reveal their specific chemical composition and age. The most characteristic feature of the studied monazite is its high uranium content which is up to $6.6 \mathrm{wt} . \% \mathrm{UO}_{2}$ in some places $(\leq 0.06$ apfu $U$ ), together with an elevated Th concentration. The actinide elements $(\mathrm{U}+\mathrm{Th})$ are incorporated together in the monazite structure through both cheralite- and huttonite-type substitutions. However, while uranium distinctly prefers the cheralite-type, $\mathrm{CaU}^{4+}(\mathrm{REE})_{-2}$ substitution mechanism, Th inclines rather towards the huttonite-type, $\mathrm{Th}^{4+} \mathrm{Si}(\mathrm{REE})_{-1} \mathrm{P}_{-1}$ trend. Unlike the commonly high Th concentrations, high $U$ enrichment is normally scarce in natural monazite. It has been reported rarely from some granitic rocks and pegmatites (e.g., Gramaccioli and Segalstad, 1978; Manucci et al., 1986; Bea, 1996; Förster, 1998; Appel et al., 2011). The origin of such noteworthy $U$ enrichment in monazite remains unresolved; high localized uranium content or an increased U/Th ratio in parental granitic magma could have important roles.

The chemical U-Th-Pb dating of monazite from both granitic samples gave a Variscan, Early Carboniferous age (346 \pm $2 \mathrm{Ma}$ ). This result concurs with a main meso-Variscan, orogenrelated granitic plutonic event in the Central Carpathian area (Tatric and Veporic Superunits). Uranium-rich monazite-(Ce) has only rarely been identified in the Central Carpathian, Variscan S-type granitic rocks; namely in some leucogranites of the Rimavica Massif (South Veporic Unit) and granites of the Bojná and Bratislava massif (northern part of the Tatric Unit). Based on recent structural and paleogeographic data, the North Tatric Zone is the most likely source of the monazite-bearing granitic clasts of the Krivá type in the Cretaceous conglomerate beds of the Pieniny Klippen Belt. However, the direct parental granitic body was most likely hidden by ensuing tectonic shortening along the northern Tatric edge after deposition of the Coniacian-Santonian conglomerates.

Acknowledgements. The authors thank A. Gawęda and B. Budzyń for constructive reviews which improved the scientific level of the manuscript and R. Marshall for corrections of the English language. This work was supported by the Slovak Research and Development Agency under contracts No. APVV-0557-06 and APVV-0465-06, and VEGA 1/0388/10.

\section{REFERENCES}

Andrusov D. (1931) Étude géologique de la zone des Klippes internes des Carpathes Occidentales. I iére partie: Introduction, II-iéme partie: Stratigraphie (Trias et Lias). Rozpravy Státního Geologického Ústavu ČSR, 6: 1-167.

Andrusov D. (1938) Étude géologique de la zone des Klippes internes des Carpathes Occidentales, III ${ }^{\mathrm{e}}$ partie: Tectonique. Rozpravy Státního Geologického Ústavu ČSR, 9: 1-135.

Andrusov D. (1968) Grundriss der Tektonik der nördlichen Karpaten. Slovak Akademische Wissenschaften Verlag, Bratislava.

Andrusov D. (1974) The Pieniny Klippen Belt. In: Tectonics of the Carpathian-Balkan Regions (ed. M. Mahel'): 145-158. Dionýz Štúr Geological Institute, Bratislava.

Appel P., Cirrincione R., Fiannacca P., Pezzino A. (2011) Age constraints on Late Paleozoic evolution of continental crust from electron microprobe dating of monazite in the Peloritani Mountains (southern Italy): another example of resetting of monazite ages in high-grade rocks. International Journal of Earth Sciences, 100: 107-123.

Bea F. (1996) Residence of REE, Y, Th and U in granites and crustal protoliths; implications for the chemistry of crustal melts. Journal of Petrology, 37: 521-552.

Birkenmajer K. (1986) Stages of structural evolution of the Pieniny Klippen Belt, Carpathians (in Polish with English summary). Studia Geologica Polonica, 88: 7-32.

Birkenmajer K. (1988) Exotic Andrusov Ridge: its role in plate-tectonic evolution of the West Carpathian foldbelt. Studia Geologica Polonica, 91: 7-37.

Birkenmajer K., Skupiński A. (1989) On some volcanic and plutonic exotic rock fragments from the Upper Cretaceous of the Pieniny Klippen Belt, Carpathians, Poland (in Polish with English summary). Studia Geologica Polonica, 97: 69-89.

Bregiroux D., Terrac O., Auduberta F., Dacheux N., Serind V., Podor R., Bernache-Assollant D. (2007) Solid state synthesis of monazite-type compounds containing tetravalent elements. Inorganic Chemistry, 46: 10372-10382.

Broska I., Uher P. (2001) Whole-rock chemistry and genetic typology of the West-Carpathian Variscan granites. Geologica Carpathica, 52: 79-90.

Dusausoy Y., Ghermani N.-E., Podor R., Cuney M. (1996) Low-temperature ordered phase of $\mathrm{CaU}\left(\mathrm{PO}_{4}\right)_{2}$ : synthesis and crystal structure. European Journal of Mineralogy, 8: 667-673.

Finger F., Broska I., Haunschmidt B., Hraško L'., Kohút M., Krenn E., Petrík I., Riegler G., Uher P. (2003) Electron-microprobe dating of monazites from Western Carpathian basement granitoids: plutonic evidence for an important Permian rifting event subsequent to Variscan crustal anatexis. International Journal of Earth Sciences, 92: 86-98.

Förster H.-J. (1998) The chemical composition of REE-Y-Th-U-rich accessory minerals in peraluminous granites of the Erzgebirge-Fichtelgebirge region, Germany. Part I: the monazite-(Ce)-brabantite solid solution series. American Mineralogist, 83: 259-272.

Förster H.-J. (2006) Composition and origin of intermediate solid solutions in the system thorite xenotime zircon coffinite. Lithos, 88: $35-55$.

Gramaccioli C.M., Segalstad T.V. (1978) A uranium- and thorium-rich monazite from a south-alpine pegmatite at Piona, Italy. American Mineralogist, 63: 757-761.

Gulson B.L., Krogh T.E. (1973) Old lead component in the young Bergell Massif, south-east Swiss Alps. Contributions to Mineralogy and Petrology, 40: 239-252.

Hovorka D., Ivan P., Mock R., Rozložník L., Spišiak J. (1990) Sediments of Gosau type near the Dobšiná Ice Cave: ideas for their non-traditional interpretation (in Slovak with English summary). Mineralia Slovaca, 22: 519-525.

Janák M., Plašienka D., Frey M., Cosca M., Schmidt S.Th., Lupták B., Méres Š. (2001) Cretaceous evolution of a metamorphic core complex, the Veporic unit, Western Carpathians 
(Slovakia): P-T conditions and in situ ${ }^{40} \mathrm{Ar} /{ }^{39} \mathrm{Ar}$ UV laser probe dating of metapelites. Journal of Metamorphic Geology, 19: 197-216.

Jeřábek P., Lexa O., Schulmann K., Plašienka D. (2012) Inverse ductile thinning via lower crustal flow and fold-induced doming in the West Carpathian Eo-Alpine collisional wedge. Tectonics, 31: TC5002, doi:10.1029/2012TC003097

Kamenický L., Kátlovský V., Marschalko R., Medved' J. (1974) Contribution to characterization of acid magmatites of exotic rocks of the Klippen Belt and other tectonic units of the West Carpathians (in Slovak with English summary). Mineralia Slovaca, 6: 311-321.

Kissová D., Dunkl I., Plašienka D., Frisch W., Marschalko R. (2005) The Pieninic exotic cordillera (Andrusov Ridge) revisited: new zircon FT ages of granite pebbles from Cretaceous conglomerates of the Pieniny Klippen Belt (Western Carpathians, Slovakia). Slovak Geological Magazine, 11: 17-28.

Kohút M., Uher P., Putiš M., Ondrejka M., Sergeev S., Larionov A., Paderin I. (2009) SHRIMP U-Th-Pb zircon dating of the granitoid massifs in the Malé Karpaty Mountains (Western Carpathians): evidence of Meso-Hercynian successive S- to I-type granitic magmatism. Geologica Carpathica, 60: 345-350.

Konečný P., Siman P., Holický I., Janák M., Kollárová V. (2004) Methodics of monazite dating using an electron microprobe (in Slovak with English summary). Mineralia Slovaca, 36: 225-235.

Krivý M. (1969) The exotic pebbles of magmatic rocks from western part of the Klippen Belt (in Slovak). Acta Geologica et Geographica Universitatis Comenianae Geologica, 18: 165-197.

Mannucci G., Diella V., Gramaccioli C.M., Pilati T. (1986) A comparative study of some pegmatitic and fissure monazite from the Alps. Canadian Mineralogist, 24: 469-474.

Marschalko R. (1986) Evolution and geotectonic significance of the Klippen Belt Cretaceous flysch in the Carpathian megastructure (in Slovak with English summary). Veda, Bratislava: 1-140.

Marschalko R., Rakús M. (1997) Development of the Cretaceous flysch in the Klape unit and the recyclicity problem of the clastic material. In: Alpine Evolution of the Western Carpathians and Related Areas (eds. D. Plašienka, J. Hók, J. Vozár and M. Elečko): 71-78. International Conference, Introduction, Articles, Excursions, Geological Survey of Slovak Republic, Bratislava.

Mišík M. (1978) Some paleogeographical problems concerning Klippen Belt. In: Paleogeographical Evolution of the West Carpathians (eds. J. Vozár et al.) (in Slovak with English summary): 147-159. Konferencie Sympózia Semináre, Dionýz Štúr Geological Institute, Bratislava.

Mišík M., Marschalko R. (1988) Exotic conglomerates in flysch sequences: examples from the West Carpathians. Mémories de la Société Géologique de France, Nouvelle Série, 154: 95-113.

Mišík M., Reháková D. (2004) Psefitic rocks (gravels, breccias, conglomerates) of the Western Carpathians (in Slovak). Veda, Bratislava.

Mišík M., Sýkora M. (1981) Der pieninische exotische Rucken, rekonstruiert aus Geröllen karbonatischer Gesteine kretazischer Konglomerate der Klippenzone und der Manín-Einheit (in Slovak with German summary). Západné Karpaty: Séria geológia, 7: 7-111.

Mišík M., Sýkora M., Mock R., Jablonský J. (1991) Paleogene Proč conglomerates of the Klippen belt in the Western Carpathians, material from Neopieninic exotic ridge. Acta Geologica et Geographica Universitatis Comenianae Geologica, 46: 9-101.

Montel J.M., Foret S., Veschambre M., Nicollet Ch., Provost A. (1996) Electron microprobe dating of monazite. Chemical Geology, 131: 37-53.

Nagy G., Draganits E., Demény A., Pantó G., Árkai P. (2002) Genesis and transformation of monazite, florencite and rhabdophane during medium grade metamorphism: examples from the Sopron Hills, Eastern Alps. Chemical Geology, 191: 25-46.

Plašienka D. (1995a) Mesozoic evolution of Tatric units in the Malé Karpaty and Považský Inovec Mts.: implications for the position of the Klape and related units in western Slovakia. Geologica Carpathica, 46: 101-112.

Plašienka D. (1995b) Passive and active margin history of the northern Tatricum (Western Carpathians, Slovakia). Geologische Rundschau, 84: 748-760.

Plašienka D. (2012) Jurassic syn-rift and Cretaceous syn-orogenic, coarse-grained deposits related to opening and closure of the Vahic (South Penninic) Ocean in the Western Carpathians - an overview. Geological Quarterly, 56 (4): 601-628.

Plašienka D., Marschalko R., Soták J., Uher P., Peterčáková M. (1994) Origin and structural position of Upper Cretaceous sediments in the northern part of the Považský Inovec Mts. Part 1: Lithostratigraphy and Sedimentology (in Slovak with English summary). Mineralia Slovaca, 26: 311-334.

Putiš M., Frank W., Plašienka D., Siman P., Sulák M., Biroň A. (2009) Progradation of the Alpidic Central Western Carpathians orogenic wedge related to two subductions: constrained by ${ }^{40} \mathrm{Ar} /{ }^{39} \mathrm{Ar}$ ages of white micas. Geodinamica Acta, 22: 1-56.

Radvanec M., Konečný P., Ondrejka M., Putiš M., Uher P., Németh Z. (2009) The Gemeric granites as an indicator of the crustal extension above the Late-Variscan subduction zone and during the Early Alpine riftogenesis (Western Carpathians): an interpretation from the monazite and zircon ages dated by CHIME and SHRIMP methods (in Slovak with English summary). Mineralia Slovaca, 41: 381-394.

Rakús M., Marschalko R. (1997) Position of the Manín, Drietoma and Klape units at the boundary of the Central and Outer Carpathians. In: Alpine Evolution of the Western Carpathians and Related Areas (eds. D. Plašienka, J. Hók, J. Vozár and M. Elečko): 79-97. International Conference, Introduction, Articles, Excursion, Geological Survey of Slovak Republic, Bratislava.

Šímová M. (1985) Magmatic rocks of the Cretaceous conglomerates from western part of the Klippen and Manín zone in the Western Carpathians (in Slovak). Západné Karpaty Séria Mineralógia Petrografia Geochémia Metalogenéza, 10: 9-110.

Shannon R.D. (1976) Revised effective ionic radii and systematic studies of interatomic distances in halides and chalcogenides. Acta Crystarllographica, A32: 751-767.

Starek D., Aubrecht R., Sliva L'., Józsa Š. (2010) Sedimentary analysis of the Cretaceous flysch sequences at the Zemianska Dedina locality (Nižná Unit, Pieniny Klippen Belt, northern Slovakia). Mineralia Slovaca, 42: 179-188.

Uher P., Broska I. (1996) Post-orogenic Permian granitic rocks in the Western Carpathian-Pannonian area: geochemistry, mineralogy and evolution. Geologica Carpathica, 47: 311-321.

Uher P., Marschalko R. (1993) Typology, zoning and geochemistry of zircon from main types of granitic and rhyolitic pebbles in conglomerates of the Pieniny Klippen Belt Cretaceous flysch (Western Slovak Segment, Western Carpathians). Geologica Carpathica, 44: 113-121.

Uher P., Pushkarev Y. (1994) Granitic pebbles of the Cretaceous flysch of the Pieniny Klippen Belt, Western Carpathians: U/Pb zircon ages. Geologica Carpathica, 45: 375-378.

Uher P., Marschalko R., Martiny E., Puškelová L'., Streško V. (1994) Geochemical characterization of granitic rock pebbles from Cretaceous to Paleogene flysch of the Pieniny Klippen Belt. Geologica Carpathica, 45: 171-183

Wieser T. (1958) Magmatic and metamorphic exotic rocks from the Cretaceous and Paleogene of the Pieniny Klippen Belt, (Carpathians) (in Polish with English summary). Biuletyn Instytutu Geologicznego, 135: 1-35.

Williams M.L., Jercinovic M.J., Hetherington C.J. (2007) Microprobe monazite geochronology: Understanding geologic processes by integrating composition and chronology. Annual Review Earth and Planetary Sciences, 35: 137-175.

Zoubek V. (1931) Caractéristique de quelques roches cristalophilliens et eruptives des galets exotiques des conglomerats sénoniens et paleogenes de Carpathes occidentales. Knihovna Státního Geologického Ústavu, 13: 353-358. 